\title{
ASSESSMENT OF SOCIAL VULNERABILITY TO THE IMPACT OF FLOOD HAZARD: A CASE STUDY OF KOPILI RIVER BASIN, ASSAM, INDIA
}

\author{
S V ShivaPrasad Sharma ${ }^{1, *}$, Parth Sarathi Roy ${ }^{2}$, Chakravarthi V ${ }^{2}$ \\ ${ }^{1}$ Disaster Management Support Division, National Remote Sensing Centre, Hyderabad, India - \\ sharma_svsp@nrsc.gov.in, \\ ${ }^{2}$ Centre for Earth,Ocean \& Atmospheric Sciences, University of Hyderabad, India - psroy13@gmail.com, \\ vcvarthi@rediffmail.com
}

\section{Commission V, SS: Disaster Monitoring, Damage Assessment And Risk Reduction}

KEY WORDS: flood risk; vulnerability index, Social Vulnerability, Kopili, Assam

\begin{abstract}
:
In the present study, an attempt is made to understand the impact on Social Vulnerability of the Kopili basin due to various severities of flood hazard. The flood hazard is generated using multi-temporal historical satellite based analysis and integration of annual flood inundation layers. The census of India data of 2001 and 2011 is spatially joined with village database to study the impact at village level. Using 5 Census variables from both Census 2001 \& 2011 as vulnerability indicators, the Social Vulnerability Index (SVI) is derived and classified into various vulnerable zones namely Low, Moderate and High Vulnerable zones. The findings of the study show that the number of villages falling in Low and High Vulnerable zones had decreased during Census 2011 when compared to 2001 and a rise of $6 \%$ in villages falling in moderate vulnerable zones during 2011 is observed. The spatial database generated is useful to understand the impact of floods on the Social Vulnerability status of the basin and can be a useful input to further study the Physical, Economic and Environmental Vulnerabilities of the basin.
\end{abstract}

\section{INTRODUCTION}

\subsection{Background}

About one-thirds of the total population around the globe is affected by floods during 1985-2003 (World Bank, 2005). India is the second most flood affected country in the world next to Bangladesh (Rao et.al, 2009). The information pertaining to damages incurred due to the impact of a flood disaster will be a prized input to the decision-makers around the globe. UN/ISDR (2002: 392) in its report has stressed the need to "develop indicators for disaster risk reduction measures." The Hyogo Framework for Action (UN/ISDR 2005b) has proposed the mandate to scientists and policy makers to monitor the disaster risk and mentions the need to put concentrated efforts on developing vulnerability indicators and risk maps at various levels as part of disaster risk reduction measures (UN/ISDR 2005a: 46).

Assessment of vulnerability for a disaster is a neglected entity as part of both research element and disaster risk reduction world over possible due to lack of data or risk perception of the society. Globally very few studies are available on the vulnerability of non-structural aspects of flooding.(Fekete, 2010). Vulnerability essentially means the potential for loss. Vulnerability is multi-dimensional like Physical, social, economic and environmental. Various studies are conducted on bio-physical vulnerability concerning the vulnerability of built environment to hazards (Mileti, 1999). The information pertaining to losses incurred due to vulnerabilities of social aspects are largely ignored due to the difficulty in quantifying them which is the very reason for absence of information in post-disaster cost estimate reports ( Cutter, et.al., 2003). Social vulnerability is more often than not describes the population / individual characteristics oomprising of age, race, health,poverty and employment ( Cutter et.al,2003; Fekete, 2009; Fekete, 2010).

to delineate areas, susceptible to floods of differing magnitudes. Drainage congestion as well as duration of flood inundation can also be studied based on sequential multi-temporal satellite imagery to help effective flood plain management. This would provide valuable inputs to regulate flood plain land use.

Sinha and Bapalu et.al, (2005) have used remote sensing images, census data and topographic maps obtained from various government agencies and computed a composite index of flood risk based on multi-parametric analysis called as Analytical Hierarchy Process (AHP). Yuko Okazawa et al., 2011 have studied that quantifying flood risk from various natural and socio-economic factors will allow us to assess how flood risk would change corresponding to the changes in population, climate and land-use conditions, and also how the policy of flood damage mitigation can potentially reduce the flood risk. The ICHARM (2007) of Japan has developed flood risk maps with hazard, vulnerability and resilience as dependent factors.

The main objective of study is to develop a Village flood risk index map based on flood hazard, land use/land cover, infrastructure and demographic data lumped at village level for Nagaon district, Assam. India has witnessed steady increase in disaster occurrences during end of twentieth century by virtue of its climate, geology and location (Joseph, 2013). The total

\footnotetext{
* Corresponding author
} 
flood prone area in the Brahmaputra valley is 3.2 Mha with the major damage experienced during the historic floods of 1954 , 1962, 1966, 1972, 1974, 1978, 1983, 1986, 1988, 1990, 1998 \& 2000 (Goswami, 1998). The state of Assam has about 9.4\% of total flood prone area of India which calls for proper flood mitigation strategy toefficiently monitor and map the flood affected areas of the region. The need to assess the impact of flood hazard disaster on the society calls for measuring social vulnerability in the region.

Satellite remote sensing technology coupled with geographic information systems has become an important tool in the recent years (Sanyal et.al, 2003). Remote Sensing plays an important role to monitor the flood affected areas on a regular basis, providing synoptic coverage over a vast area in cost effective manner. The flood hazard zonation coupled with flood risk assessment of damages can serve as one of the effective tool for assessing the flood damages.

Coppock (1995) reviews the application and role of geographic information system in the management of multi-dimensional natural hazard management with an inherent spatial component. GIS is advantageous and useful in both visualization of flooding and as well as in estimation of damages due to flood (Haussmann et al., 1998; Clark, 1998).(Karmakar et.al, 2010) reviews the need for assessment and mapping of flood risk and vulnerability taking into account the damage incurred to critical facilities, emergency service stations and road bridges and emphasises the effectiveness of sharing information to stakeholders as means of reliable flood management process.

The Present research is motivated by Village risk index and Risk-Vulnerability assessment to flood (Sharma et, al, 2012; Karmakar et.al, 2010). The development of village flood risk index estimates and classifies the village flood riskby combining the flood hazard zonation with various vulnerability indices derived at village level whereas Risk-Vulnerabilty assessment to flood combines the four components of vulnerability (Physical, Social, Economic \& Infrastructure) with soil permeability and land use./cover and their dependence on severity of flood.

This paper aims to derive the Social Vulnerability Index (SVI) of the Kopili river basin taking number of households, female population, poverty and illiteracy as the indicators for deriving the Social vulnerability index with village as a stratum.

\section{MATERIALS AND METHODS}

\subsection{Study Area}

Kopili basin extends from $91-93^{\circ} \mathrm{E}$ long. and $25-27^{\circ} \mathrm{N}$ lat. (Figure 1).The total geographical area (TGA) is 1355600 hectares. The basin is drained by Kopili river, one of the principal south bank tributaries of Brahmaputra River which originates from the south-western slope of the Shillong peak (Kusre et.al, 2010). The basin has sub-dendritic drainage pattern and is a combination of hill ranges, plateau and alluvial plains. The elevation varies between $60 \mathrm{~m}$ to $2000 \mathrm{~m}(\mathrm{msl})$ and is dissected by various sub-tributaries contributing flow to Kopili river system (Chetry and Saikia, 2002). The average rainfall ranges between $2000 \mathrm{~mm}$ to $3000 \mathrm{~mm}$ with more than $80 \%$ of the rainfall occurring during the short south-west monsoon season of June-September. The maximum of $44^{\circ} \mathrm{C}$ temperatures is observed during hot summer season and a minimum of $4^{\circ} \mathrm{C}$ is observed during winters. The basin is mainly dominated by forest due to its physiographic, climate and geology. According to Census 2011 survey, the total population of Assam State is estimated at 3.12 Crore as against the Census 2001 which was 2.67 Crore (http://www.census2011.co.in/census/state/assam.html). A decadal growth of $17 \%$ is observed. (Singh et.al.,2017).

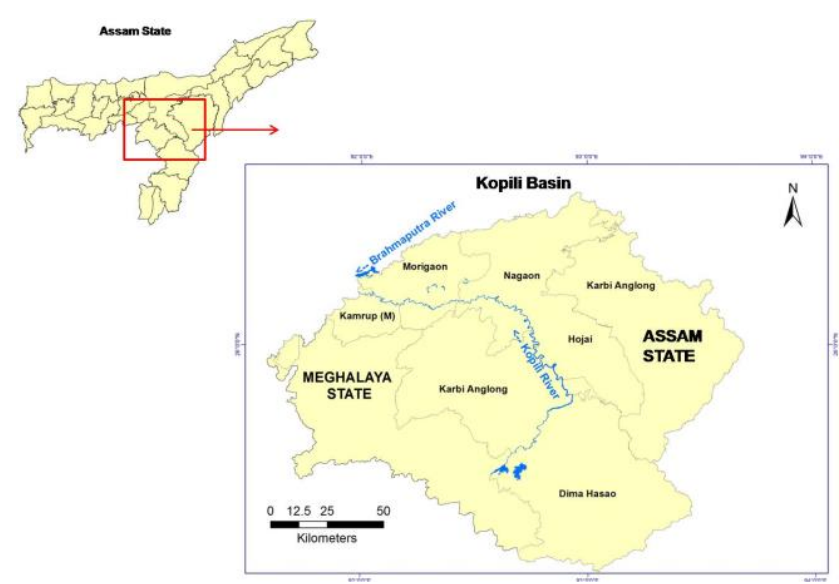

Fig 1: Location Map of the study area

\subsection{Datasets}

The flood hazard zonation layerof Kopili river basin was derived from the extraction of flood inundation layers acquired during the flood seasons of 1998-2015 from both optical (Indian Remote Sensing (IRS)) and microwave (RADARSAT Canadian microwave satellite\& Indian microwave satellite RISAT-1) satellite datasets. The Census of India data pertaining to the year 2001 and 2011 were procured and spatially joined to the aspatial database of village layer of Kopili basin extracted from Assam State database for further analysis.

\subsection{Preprocessing of Satellite data}

It is necessary to correct the images geometrically and radiometrically. The satellite data analysis is carried out using image processing software. The satellite datasets (both optical and microwave) were geometrically rectified (Lambert Conformal Conic/Modified Everest projection). For IRS series datasets, geometric correction was done using pre-rectified AWiFS master images.. In case of SAR data the sigma nought (back scattered image) is generated first using image processing techniques and then co-registered with respective state masters for positional accuracy. All datasets were corrected with sub pixel accuracy.

\subsection{Image Classification}

The satellite data acquired during floods is geocoded with the respective master datasets. In case of optical data, unsupervised classification is performed giving maximum number of classes and main active river channel, its tributaries and permanent water bodies are classified. Since signature of cloud edges mixes with water signature care is taken while applying post editing tools of classification. In case of microwave data, back scattering image (sigma nought) is generated and water bodies are extracted using variable threshold method for automatic delineation of flood inundation using Radarsat SAR data (Srinivasulu, J., et al, 2005). State mask, hill mask, hill shadow mask are applied on the extracted water layer. Further, stray water pixels are separated by grouping and eliminating. 


\section{METHODOLOGY}

Vulnerability is broadly defined as the susceptibility to suffer loss or damage (Cutter, 1996). Based on the social science research, the "vulnerability" is the human condition as opposed to physical structures, economies or locations (Wisner et al. 2004). Vulnerability is further sub-divided into four different types such as physical, social, economic and environmental variability. Social Vulnerability in particular deals with the criteria pertaining to communities, number of households, age, gender, source of income etc by assigning different weightages to various indicators listed above which have a potential to directly or indirectly hamper the functioning of the community/household or an individual or groups of people in the adverse event of a natural hazard.

In the present study the social vulnerability index is derived for Kopili river basin by using indicators comprising of No. of Households, Female Population, Population of Scheduled Castes/Tribes (SC/ST) (People below the poverty line) and population comprising of illiterates as potential indicators to arrive onto the social vulnerability index taking village as stratum. The village spatial database of Kopili basin is joined to the census of India data of the years 2001 and 2011. The village database after joining with census data is integrated with the flood hazard zonation layer of Kopili basin to assess the impact of flood inundation on the demography of the area to observe the effect of human susceptibility to varying severities of flood hazard.

Based on the analysis of historical satellite datasets acquired during the flood seasons of 1998-2015, the flood inundation layers are extracted and integrated to form an annual layer, a composite flood hazard zonation layer is prepared by integrating all the annual flood layers from 1998-2015 representing the number of times(occurrences) an area is inundated. The flood hazard zonation layer is further subdivided into five flood hazard severity classes namely very low, low, moderate, high and very high with very high (almost every year) hazard zone representing the worst flood affectedarea and very low (atleast once) being the least flood affected area. The weightages are assigned from 1 to 5 with 5 being very high and 1 is very low hazard category.

\subsection{Social Vulnerability Index}

Social Vulnerability essentially encompasses susceptibility of humans and their conditions to cope with natural hazards for their survival and adaptation (Hilhorst and Bankoff, 2004:2).Census India data of 2001 and 2011 were joined with the Kopili basin village database so as to derive the demography data at village level during 2001 and 2011. Vulnerability according to Vogel and O' Brien (2004:4) is mulit-dimensional, differential, scale dependent and dynamic.

Social vulnerability according to Cannon et al (2003: 5)is driven by the indicators such as livelihood, resilience, selfprotection, proximity to impending hazards and the negative impact of an hazardous event on the community. In the present study, to assess the impact of flood hazard on the population and its associated impacts in long term, different time frames of census data 2001 and 2011 were utilised and a comparative assessment with regards to flood hazard zonation layer (19982015) is derived.

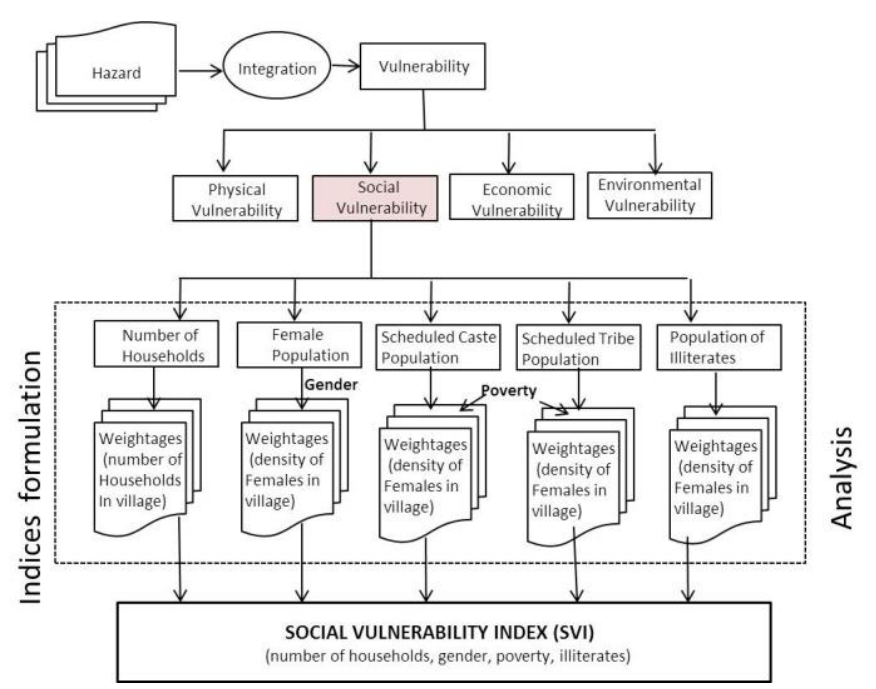

Figure 2: Flow chart showing the methodology to derive Social

Vulnerability Index

Weightages to the indicators (household composition, female population (gender), scheduled caste/tribe (poverty) and population of illiterates) were assigned based on the impact of flood hazard on the indicator systems and its potential adverse impacts it can possibly have on the community. There is a global consensus that disaster vulnerability not only results due to physical and infrastructure related systems but also results from social and demographic characteristics of the communities (Mileti 1999). Hence forth higher weightages were assigned to villages comprising of higher number of households, female population, people in poverty and illiterates. The sum total of all vulnerability indices derived from House hold vulnerability, female population vulnerability, Population vulnerability of Scheduled caste/tribe and population vulnerability of illiterates is Social Vulnerability Index (SVI).

\section{Results \& Discussions}

Vulnerabilities are basically assessed using set of indicators or indicator systems and weightages are being assigned to the indicators to identify the level of vulnerabilities ranging from very high to very low or high to low at different scales and the level of impact they would have on the recovery of the community when faced with a hazard situation. Social vulnerability Index, in the present study is assessed by using the impact of flood hazard on the household composition, female population, population of SC/ST and population of illiterates on the social and demographic characteristics of villages in Kopili river basin.

\subsection{Household Composition}

The vulnerability of number of households in a village to flood hazard impact is assessed by assigning weightages for various flood hazard severities ranging from very high to very low hazard zones. The villages in which number of households greater than 600 are categorised in Very high vulnerabilityzone and less than 150 households in a village are classified under very low vulnerability zones. It is observed that more than $16 \%$ of the households are falling under very high vulnerable zones during Census, 2011 as against 7\% households fell under very high zones during Census, 2001 period which is 9\% increase during 2011. About $30 \%$ of households were in low vulnerable zone during Census 2001 with $8 \%$ and $6 \%$ decrease in number 
of households in very low to low categories respectively during 2011 as shown in Table 1.

Table 1: Household Composition Vulnerability Index

\begin{tabular}{l|l|l|l|r|r|r|}
\hline & & \multicolumn{2}{|c|}{$\mathbf{2 0 1 1}$} & \multicolumn{2}{|c|}{$\mathbf{2 0 0 1}$} & \\
\hline Household losses & $\begin{array}{l}\text { Hazard } \\
\text { Intensity }\end{array}$ & $\begin{array}{l}\text { No of } \\
\text { villages }\end{array}$ & $\begin{array}{l}\text { \% } \\
\text { damage }\end{array}$ & $\begin{array}{l}\text { No of } \\
\text { villages }\end{array}$ & $\begin{array}{l}\text { \% } \\
\text { damage }\end{array}$ & $\begin{array}{l}\text { Weighta } \\
\text { ges }\end{array}$ \\
\hline $0-150$ & Very Low & 319 & 32 & 401 & 40 & 1 \\
\hline $151-300$ & Low & 244 & 24 & 302 & 30 & 2 \\
\hline $301-450$ & Moderate & 179 & 18 & 155 & 16 & 3 \\
\hline $451-600$ & High & 97 & 10 & 75 & 8 & 4 \\
\hline 700 & Very High & 160 & 16 & 66 & 7 & 5 \\
\hline & TOTAL & $\mathbf{9 9 9}$ & $\mathbf{1 0 0}$ & $\mathbf{9 9 9}$ & $\mathbf{1 0 0}$ & \\
\hline
\end{tabular}

\subsection{Gender (Female Population)}

It is observed globally that many studies attributed to social vulnerability have given significant importance and emphasis to female population which has a direct/indirect bearing in arriving to vulnerability assessment for a region/county/locality etc. In the present study, depending on the numbers of female population in a given village, weightages are assigned. Utilising the census of India data of 2001 and 2011, female population at village level is considered and spatially joined to village database to derive village-wise population of females. High weightages were assigned to villages with female population exceeding 1000 and lower weightages were assigned to villages whose female population is below 500. The female population vulnerable to high vulnerability is assessed as $31 \%$ during 2011 as against $23 \%$ during 2001 census data (Table 2). A total of 306 villages fall in high category during 2011 as against 228 villages during 2001.

Table 2: Female Population Vulnerability Index

\begin{tabular}{|l|l|r|r|r|r|r|}
\hline & & \multicolumn{2}{|c|}{2011} & \multicolumn{2}{|c|}{$\mathbf{2 0 0 1}$} & \\
\hline $\begin{array}{l}\text { Female } \\
\text { Population }\end{array}$ & Hazard Intensity & $\begin{array}{l}\text { No of } \\
\text { villages }\end{array}$ & $\begin{array}{l}\text { \% } \\
\text { damage }\end{array}$ & No of villages & $\begin{array}{l}\text { \% } \\
\text { damage }\end{array}$ & Weightages \\
\hline $1-500$ & Low & 414 & 42 & 472 & 47 & 1 \\
\hline $501-1000$ & Moderate & 277 & 28 & 299 & 30 & 2 \\
\hline$>1000$ & High & 308 & 31 & 228 & 23 & 3 \\
\hline & TOTAL & 999 & 100 & 999 & 100 & \\
\hline
\end{tabular}

\subsection{Poverty (Population of SC/ST)}

Yoon (2012) in his study states that the achieved social status of residents, which includes the percentage of people living in property as the most statistically significant indicator of vulnerability. The people living in poverty in this case the population of SC/ST involve more damages to livestock and property due to natural disasters. This indicator is very important especially in a country like India mainly due to the tremendous population pressure on landuse and tendency to intrude flood plains leading to significant damages. The census of India data of 2001 and 2011 is joined to village database of Kopili basin and weightages are assigned to various hazard intensities. Table $3 \& 4$ shows that during 2001 census about $45 \%$ of villages consisting of Population of Scheduled castes were relatively unaffected as against 37\% during 2011 and similarly $57 \%$ of population of scheduled tribes were unaffected during census 2001 as against 44\% during census 2011. It is observed that there is not much increase or change in the percent damage of population of SC/ST during 2011 and 2001.

Table 3: Population of SC Vulnerability Index

\begin{tabular}{|l|l|r|r|r|r|r|}
\hline & & \multicolumn{2}{|c|}{$\mathbf{2 0 1 1}$} & \multicolumn{2}{|c|}{$\mathbf{2 0 0 1}$} & \\
\hline $\begin{array}{l}\text { Population of } \\
\text { SC }\end{array}$ & $\begin{array}{l}\text { Hazard } \\
\text { Intensity }\end{array}$ & $\begin{array}{l}\text { No of } \\
\text { villages }\end{array}$ & $\begin{array}{l}\text { \% } \\
\text { damage }\end{array}$ & $\begin{array}{l}\text { No of } \\
\text { villages }\end{array}$ & $\begin{array}{l}\text { \% } \\
\text { damage }\end{array}$ & $\begin{array}{l}\text { Weigh } \\
\text { tages }\end{array}$ \\
\hline $1-50$ & Low & 203 & 20 & 167 & 17 & 1 \\
\hline $51-300$ & Moderate & 201 & 20 & 196 & 20 & 2 \\
\hline$>300$ & High & 221 & 22 & 189 & 19 & 3 \\
\hline 0 & Unaffected & 374 & 37 & 447 & 45 & 0 \\
\hline & TOTAL & 999 & 100 & 999 & 100 & \\
\hline
\end{tabular}

Table 4: Population of ST Vulnerability Index

\begin{tabular}{|l|l|r|r|r|r|r}
\hline & & \multicolumn{2}{|c|}{$\mathbf{2 0 1 1}$} & \multicolumn{2}{|c|}{ 2001 } & \\
\hline $\begin{array}{l}\text { Population } \\
\text { ofST }\end{array}$ & $\begin{array}{l}\text { Hazard } \\
\text { Intensity }\end{array}$ & $\begin{array}{l}\text { No of } \\
\text { villages }\end{array}$ & $\begin{array}{l}\text { \% } \\
\text { damage }\end{array}$ & $\begin{array}{l}\text { No of } \\
\text { villages }\end{array}$ & $\begin{array}{l}\text { \% } \\
\text { damage }\end{array}$ & $\begin{array}{l}\text { Weight } \\
\text { ages }\end{array}$ \\
\hline $1-50$ & Low & 263 & 26 & 166 & 17 & 1 \\
\hline $51-300$ & Moderate & 164 & 16 & 153 & 15 & 2 \\
\hline$>300$ & High & 134 & 13 & 116 & 12 & 3 \\
\hline 0 & Unaffected & 438 & 44 & 564 & 57 & 0 \\
\hline & TOTAL & 999 & $\mathbf{1 0 0}$ & $\mathbf{9 9 9}$ & $\mathbf{1 0 0}$ &
\end{tabular}

\subsection{Literacy rate}

The vulnerability of a region to natural disasters is dependent on poverty, unemployment, disability, education level, occupation etc (Yoon, 2012). The villages in Kopili basin wherein the population of illiterates is concentrated is considered as one of the significant indicator of vulnerability to losses when faced with a flood hazard situation whose education level is none and are unemployed. The villages with population greater than 1000 are assigned higher weightages and population below 250, lower weightages are assigned. About $25 \%$ of villages whose population greater than 1000 are considered in Very High vulnerable zones during both the census years of 2001 and 2011.No significant change in population of illiterates in moderate, low and very low is observed during two census years as shown in Table 5 .

Table 5: Population of Literacy

\begin{tabular}{|l|l|l|r|r|r|r|}
\hline & & \multicolumn{2}{|c|}{2011} & \multicolumn{2}{|c|}{2001} & \\
\hline $\begin{array}{l}\text { Illiterate } \\
\text { Population }\end{array}$ & $\begin{array}{l}\text { Hazard } \\
\text { Intensity }\end{array}$ & $\begin{array}{l}\text { No of } \\
\text { villages }\end{array}$ & $\begin{array}{l}\text { \% damage } \\
\text { No of } \\
\text { villages }\end{array}$ & $\begin{array}{l}\text { \% } \\
\text { damage }\end{array}$ & Weightages \\
\hline $1-250$ & Very Low & 344 & 35 & 296 & 30 & 1 \\
\hline $251-500$ & Low & 220 & 22 & 226 & 23 & 2 \\
\hline $501-750$ & Moderate & 118 & 12 & 137 & 14 & 3 \\
\hline $751-1000$ & High & 78 & 8 & 92 & 9 & 4 \\
\hline$>1000$ & Very High & 239 & 24 & 248 & 25 & 5 \\
\hline & TOTAL & 999 & 100 & 999 & 100 & \\
\hline
\end{tabular}

\section{Social Vulnerability Index (SVI)}

The Social vulnerability Index (SVI) is given by the following formula

Social Vulnerability Index $($ SVI $)=$ Sum $($ Household composition index+ female population index(gender) + population of SC/ST (Poverty) Index + Illiterate Population Index)

SVI is calculated based on the vulnerability indicators household composition, gender, poverty and population of illiterates for the census years of 2001 and 2011 and based on this SVI in Low, Moderate and High vulnerable zones are identified.

The vulnerability of a region to natural disasters is dependent on poverty, unemployment, disability, education level, occupation etc (Yoon, 2012). The villages in Kopili basin wherein the population of illiterates is concentrated is considered as one of the significant indicator of vulnerability to losses when faced with a flood hazard situation whose education level is none and are unemployed. The villages with population greater than 1000 are assigned higher weightages and population below 250, lower weightages are assigned. About 25\% of villages whose population greater than 1000 are considered in Very High vulnerable zones during both the census years of 2001 and 2011.No significant change in population of illiterates in moderate, low and very low is observed during two census years as shown in Table 6shows that during 2001 about 765 villages were in Low category as against 735 villages in 2011. The number ofvillages in high vulnerable zone have reduced by $3 \%$ which is from 38 to 7 villages during 2011 and number of villages falling in moderate have increased by $6 \%$ during 2011 showing a normal trend of population growth in total hazard centric areas. Figure $3 \& 4$ 
shows the Social Vulnerability Index of 2001 and 2011 respectivelyof the villages of Kopili basin overlaid on the shaded relief image of Shuttle Radar Topographic Mission (SRTM) DEM of 30 meter spatial resolution downloaded from https://earthexplorer.usgs.gov/ generated using shaded relief tool from topographic analysis of Erdas IMAGINE 13.0 software.

Table 6 : Social Vulnerability Index (SVI)

\begin{tabular}{|l|l|l|l|l|r|}
\hline & \multicolumn{2}{|c|}{2011} & \multicolumn{2}{|c|}{2001} \\
\hline $\begin{array}{l}\text { Social } \\
\text { Vulnerability } \\
\text { Index(SVI) }\end{array}$ & $\begin{array}{l}\text { Hazard } \\
\text { Intensity }\end{array}$ & $\begin{array}{l}\text { No of } \\
\text { villages }\end{array}$ & $\begin{array}{l}\text { \% } \\
\text { damage }\end{array}$ & $\begin{array}{l}\text { No of } \\
\text { villages }\end{array}$ & \%damage \\
\hline $0-12$ & Low & 735 & 74 & 765 & 77 \\
\hline $13-18$ & Moderate & 257 & 26 & 196 & 20 \\
\hline $19-33$ & High & 7 & 1 & 38 & 4 \\
\hline & TOTAL & 999 & 100 & 999 & 100 \\
\hline
\end{tabular}

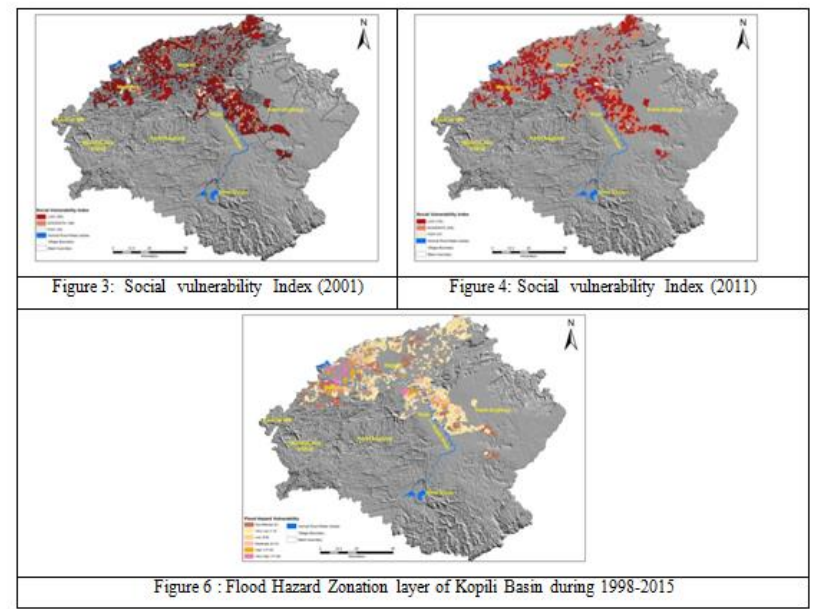

The Kopili basin lies in the Central Valley region of Assam State which is actually a rain shadow zone covered by hilly regions of Karbi Anglong hills and Dima Hasao (formerly North Cachar Hills) which has low annual rainfall of 800-1200 $\mathrm{mm}$ (Das, 2009). The area's location of rain shadow zone and absence of effective irrigation systems coupled with lack of water harvesting mechanisms in the vicinity leads to vulnerability of the people. In addition, the area has a flat terrain surrounded by hills. Due to the concentration of short annual rainfall between June-September, it puts tremendous pressure of evacuating its rainwater and water contributed by its small tributaries in the region to the Kopili River leading to overtopping its banks and inundating adjacent areas. Kopili basin mainly comprises of rural population and Nagaon is the principal town with large urban population and is relatively unaffected by flood hazard incidences. Most of the population is concentrated in villages with agriculture as their prime occupation.

The Social Vulnerability index (SVI) observed during the census of 2001 and 2011 has shown that number of villages concentrated in Low and High category have reduced by almost $4 \%$ and a $6 \%$ increase in the moderate vulnerability category is observed. The Maroon red color shown in Figures (3 \&4) indicates low vulnerable regions which are mainly concentrated on the banks of Kopili river understandably they are within the flood plains of the Kopili river and also in the low lying areas and are less frequently affected by floods during 1998-2015 as shown in figure 6 .

\section{Conclusions}

In the present study, using Census of India demography data of 2001 and 2011, an attempt has been made to make a comparative assessment of the impact of flood hazard on the population centres of Kopili river basin and to understand the decadal change in population trend in flood hazard affected areas at a village level. A Village level Social Vulnerability Index is derived using various vulnerability indicators which bear significant importance on the recovery/resilience of village after flood hazard impact. The spatial database is generated at a village level which is a very finer level of database attempted for the Kopili river basin as part of deriving social vulnerability index. This database is a very useful and a primary input towards formulating Village Vulnerability Maps. With the addition of age, type \& size of household a very comprehensive Social vulnerability Index can be derived. This database can be served as an input to assessing the Physical, Economic and Environmental vulnerability of the village.

\section{Acknowledgements}

The authors are grateful to Director, National Remote Sensing Centre (NRSC), Hyderabad, Deputy. Director, Remote Sensing Applications Area (RSAA),Staff of Disaster Management Support Group (DMSG) and staff of Centre for Earth,Ocean \& Atmospheric Sciences for their encouragement and providing necessary expert guidance and facilities to carry out the work. Landsat archived data\& SRTM DEM $30 \mathrm{~m}$ available from USGS is also acknowledged.

\section{References}

Birkmann, Jörn (UNU-EHS): Measuring vulnerability Measuring Vulnerability to Natural Hazards Towards Disaster Resilient Societies. http://www.ehs.unu.edu/article:279

Cutter SL (1996) Vulnerability to environmental hazards. Prog Hum Geogr 20:529-539

Cutter, S. L., Boruff, B. J. and Shirley, W. L. (2003), Social Vulnerability to Environmental Hazards*. Social Science Quarterly, 84: 242-261. doi:10.1111/1540-6237.8402002

Chetry, N.; Saikia, R. (2002). Atlas of resources, Infrastructure and development. An publication of the output of the Department of Science and Technology Sponsored Project on Integration and Management of Multi-Source Data Using GIS for Development Plan/ Strategy for Kathiatoli Development Block within Kopi/i Basin in North East India. ; Department of Geography, Cotton Col/ege Guwahati. 52p.

Chandramouli C. 2011. Census of India. Provisional population totals, paper 1 of 2011, India, Series 1. Office of Registrar General and Census Commissioner. 188. Available from: http://www.censusindia.gov.in/2011-provresults/prov_results_paper_india.html [cited 2 july 2012].

Clark, M. J.: 1998, Putting water in its place: A perspective on GIS in hydrology and water management, Hydrological Processes 12, 823-834.

Coppock, J. T.: 1995, GIS and natural hazard: an overview from a GIS perspective, In: A. Carrara and F. Guzzetti (eds), Geographical Information System in Assessing Natural Hazard, Kluwer Academic, Netherlands, pp. 21-34.

Cannon, T., J.Twigg and J.Rowell (2003) “ Social Vulnerability, sustainable Livelihoods and Disasters', Report to DFID conflict and Humanitarian Assistance Department 
(CHAD) and Sustainable Livelihoods Support Office available at http:// www.livelihoods.org/static/tcannon_NN197.htm

Das, Partha J. "Water and climate induced vulnerability in northeast India: concerns for environmental security and sustainability." WATCH Resercah Report 1 (2009).

Fekete, A.: Validation of a social vulnerability index in context to river-floods in Germany, Nat. Hazards Earth Syst. Sci., 9, 393-403, doi:10.5194/nhess-9-393-2009, 2009.

Fekete, Alexander. Assessment of Social Vulnerability River Floods in Germany. Ed. Katharina Brach. United Nations University, Institute for Environment and Human Security (UNU-EHS), 2010.

Goswami DC (1985) Brahmaputra River, Assam, India: Physiography, Basin Denudation, and Channel Aggradation. Water Resources Research 21: 959-978

Goswami DC (1998) Fluvial Regime and flood hydrology of the Brahmaputra River, Assam, India: Kale VS (ed), Flood Studies in India. Geol. Soc. India, Memoir 41: 53-75

Hilhorst, D. and Bankoff (2004) "Introduction: Mapping Vulnerability", in G.Bankoff, G.Freks and D.Hilhorst, eds, Mapping Vulnerability: Disasters, Devlopment and People, London: Earthscan, pp.1-9.

Hausmann, P. and Weber, M.: 1988, Possible contributions of hydroinformatics to risk analysis in insurance, In: Proc. 2nd International Conference on Hydroinformatics, Zurich, Switzerland, 9-13 September, Balkema, Rotterdam.

Horritt, M. S., and P. D. Bates. "Evaluation of 1D and 2D numerical models for predicting river flood inundation." Journal of hydrology 268.1 (2002): 87-99.

Kusre, B.C., D.C. Baruah, P.K. Bordoloi, and S.C. Patra. 2010. Assessment of hydropower potential using GIS and hydrological modeling technique in Kopili River basin in Assam (India). Applied Energy, Vol. 871,pp 298-309.

Mileti D (1999) Disasters by design: A reassessment of natural hazards in the United States. D.C., JosephHenry Press, Washington

Rao, KHVDurga, V. Bhanumurthy,and P. S. Roy. "Application of satellite-based rainfall products and SRTM DEM in hydrological modelling of Brahmaputra basin." Journal of the Indian Society of Remote Sensing 37.4 (2009): 587-600.

Sharma, Prasad, et al. "Development of village-wise flood risk index map using multi-temporal satellite data: a study of Nagaon district, Assam, India." Current Science (00113891) $103.6(2012)$

Sanyal, Joy, and X. X. Lu. "Application of remote sensing in flood management with special reference to monsoon Asia: a review." Natural Hazards 33.2 (2004): 283-301.

Singh, S., Reddy, C. S., Pasha, S. V., Dutta, K., Saranya, K. R. L., \& Satish, K. V. (2017). Modeling the spatial dynamics of deforestation and fragmentation using Multi-Layer Perceptron neural network and landscape fragmentation tool. Ecological Engineering, 99, 543-551.
Joseph, Jacquleen "Measuring vulnerability to natural hazards: a macro framework." Disasters 37.2 (2013): 185-200.

UNISDR, May. "UNISDR Terminology for Disaster Risk Redution." United Nations International Strategy for Disaster Reduction (UNISDR) Geneva, Switzerland (2009).

UN/ISDR (2005b): Hyogo Framework for Action 2005-2015: Building the resilience of nations and communities to disasters (HFA), UN/ISDR - Inter-Agency Secretariat of the International Strategy for Disaster Reduction, United Nations, Geneva.

UN/ISDR (2002): Living with Risk. A global review of disaster reduction initiatives., UN/ISDR - Inter-Agency Secretariat of the International Strategy for Disaster Reduction, 2004 version, United Nations, Geneva.

Vogel, C. and K. O’Brien (2004) “Vulnerability and Global Environmental Change: Rhetoric and Reality", AVISO 13:1-7 Wisner B, Blaikie P, Cannon T, Davis I (2004) At risk: natural hazards. People's Vulnerability and Disasters, New York, NY, Routledge

Yoon, D. K. (2012). Assessment of social vulnerability to natural disasters: a comparative study. Natural Hazards, 63(2), 823-843.

World Bank, 2005, Natural Disaster Hotspots: A Global Risk Analysis. Washington DC: World bank Publications. 